The shape of the orbit at once suggests the reflecting cone of a thermopile, with the eyeball centred on its axis in the position of the pile, but of course much less deeply placed. The cone is, in this case, oblique, the maximum slant side being internal, i.e. towards the nose, and the minimum slant side external. A plane through the outer orbital angle, and perpendicular to the axis, will be pretty nearly coincident with the tangential plane of the eyeball at the anterior end of its antero-posterior diameter, and there will be a considerable part of the nasal surface of the cone in front of that plane. This part will act as a reflecting surface, and concentrate the rays upon the eyeball Probably variations of complexion will not much affect the reflecting power of this surface, seeing that the difference in the skin of black and of white races is mainly a difference in the amount of pigment in the rete mucosum, and not in the superficial parts of the epidermis.

It is evident that rays reflected from the ground, and from objects of no great altitude, are the rays which will have the greatest chance of striking the eye after reflection from the side of the orbital cone. The direct rays of the sun in tropical countries will, during the hottest part of the day, be too nearly vertical to take this course. Now it would seem that it is in the case of intense light reflected from rocks, snow, \&c., that the blackening has been found useful.

Whether to any appreciable extent the amount of light entering the eye is increased by the shape and projection of the orbit is a different question. For here it is not enough that the rays should be concentrated upon the eyeball. They must enter the pupil. Nevertheless, it would seem from observations made fo another purpose : $\mathrm{m}$ the pupil-reflex, that the diameter of the aperture is increased by blackening the skin round the orbit, say by means of a piece of black cloth with an elliptical hole in i for the eye, the light of course being ke $t o^{c}$ ? constant intensity. April 19 G. N. S.

\section{On the Form of Mole-Hills Thrown up under Snow}

MOLES must have an opportunity of getting to the surface here and there to dispose of the results of their excavations. When they meet with a deep-laid hard road they come out and cross it. When frost has bound the soil into an impenetrable cake they sometimes come out of the ground, and, travelling away to seek a place more suitable for their operations, are unable to find their way back or to burrow into the frozen soil in another place,

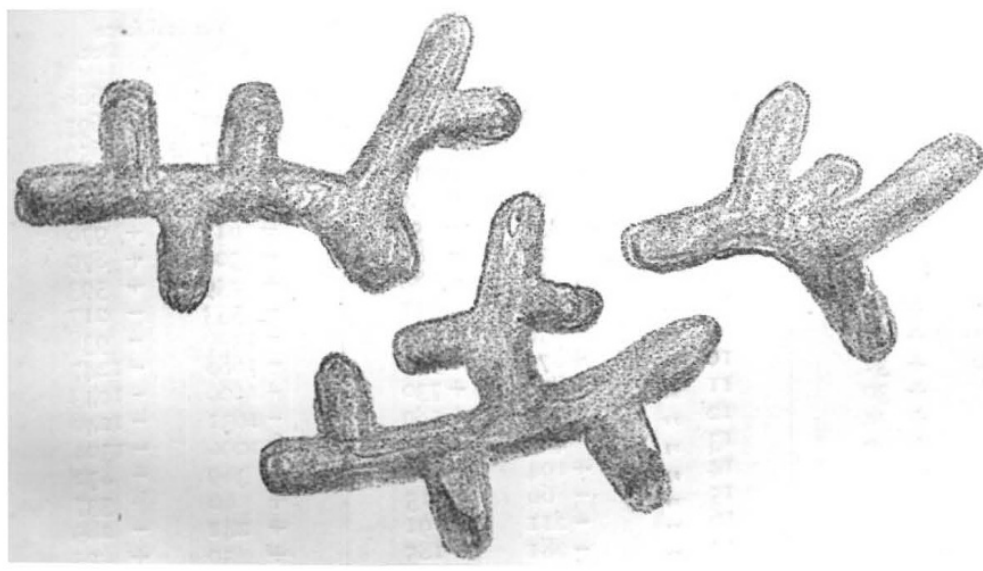

and 'so they get killed in considerable numbers. When there is a little snow on the ground, protecting it from the frost, the moles come to the surface as usual, and throw up mounds of earth under or through the snow. But, when deep-drifted snow has covered the ground, the mole-hills under it are found to be arranged in more or less symmetrical ridges of uniform height and breadth, as represented in the sketch. It would appear that the moles in these circumstances make galleries about the size of their own bodies on the surface of the turf in the bottom of the snow, into which they push the earth to be disposed of, finding it easier to make these small tunnels than to raise the usual mound of earth under the superincumbent snow-drift. The severe winter just over has caused the snow-drifts to lie long in the north of England, where examples of this peculiar form of mole-hill may be commonly seen on the Fells.

Cambridge

Thos. McKenny Hughes

\section{Protective Imitation}

I IAVE been watching for hours with great interest what I believe to be a very curious instance of protective imitation. A large old thrush has been, all that time, trying to make itself look like a serpent, and succeeding remarkably well. The object appears to be to frighten away a smaller and more active thrush-no doubt younger and with sharper ear:-which seems to be getting all the worms. It appears afraid to attack its young rival, but runs towards it as if it meant to do so, and when the young one turns round and faces it, the old one crouches down so that nothing of it is seen but a crest-like back, two glaring eyes, the spotted throat, and a dark line formed by the front view of the beak and the lines at the corners of the mouth, which look very much like a serpent's mouth. If I saw the creature protruding from a bush or from the grass, I should certainly take it for a snake of some kind. The young bird looks alarmed and retreats, though just before it was ready to attack the other. No sooner has it recovered its courage and advanced to attack than the old one retreats, and resumes its serpent-like mask. There has been a little sparring in the air occasionally, just enough to show the nature of the feeling, but if allowed to do so the young one evidently would be content to feed quietly. The old thrush (I know it by a small white feather on one wing) is very much at home on this lawn, and seems to consider it as its own private domain, at all events as far as thrushes are concerned. A short time ago, when the ground was for a long time hard from frost and drought, this thrush moped about and seemed nearly starved, and at last fell upon two great clumps of yellow crocuses, and not only tore them to pieces, as if in a rage, but devoured them entirely, returning again and again to them, and gobbling up the yellow petals as a rabbit does a lettuce. At that time many birds that are usually too shy came down from the hills and strolled about the fields and lawns-snipes, plovers, \&c. Two exquisite crested plovers (I think they are called) stalked about with graceful dignity for some days in a garden close by, and roosted in an old henhouse. The thrush touched no crocuses but the yellow ones, and no other bird did so. I should be glad to know if the resemblance to a serpent has been observer by any one else.

Sidmouth, April I9

J. M. H.

P.S.-It may be thought that the crouching is only a preparation for a spring, but it does not suggest that to the eye, and it is not followed by a spring. If it really is a fact and not a fancy, the instincts of imitation and of fear in this case must be a very ancient in. heritance indeed.

\section{Iridescent Clouds}

TIIIs evening at sunset there was here a fine instance of iridescent clouds. About 7 I drew the attention of my companion to some remarkable clouds; three long arms of stratus of peculiar texture, like pulled-out cotton-wool, and of striking colour, blue-black and silver, stretched nearly to where the sun had gone down behind a hill. At 5 minutes past 7 a detached portion of this cloud assumed lovely iridescent colours like bright mother-of-pearl.

This gradually died away, but other portions assumed the same tints. At 7.30 the tints vanished. Wind, south to south-west. Glencar, Kerry, April 26

J. G. Grenfelt

\section{MADRAS MAGNETICAL OBSERVATIONS 1}

WE are indebted for the present volume to $\mathrm{Mr}$. Pogson, the Government Astronomer at Madras, from whose introductory remarks we learn that he is not yet at the end of his editorial labours.

I "Magnetical Observations made at Madras in the Years $185 \mathrm{r}-\mathrm{I} 855$, under the Superintendence of Mr. W. S. Jacob." Edited by Mr. N. R. Pogson, Government Astronomer. (Madras: Lawrence Asylum Press, 1884.) 
Mr. Pogson intends as soon as possible to continue his work, and the greatest praise must be given to this distinguished astronomer for his persistent efforts to complete the records of his Observatory. But what can be thought of a system of administration under which observations are reduced about half a century after they are made? If this were the only instance of such a monstrous delay it would be bad enough, but we seem destined to have another instance, no less flagrant. The late Mr. John Allan Broun finished his work at the Trevandrum Observatory in 1864, and as yet only the first volume of his reductions has seen the light. Here the Observatory has been discontinued, and we do not know that any one has come forward to complete the labours of Mr. Broun, so that the publication of the remaining volumes seems to be adjourned indefinitely. Surely there is something in this system which requires putting right.

Mr. Pogson tells us in his introduction that the vertical force results were never entitled to any confidence, especially before March I 853 , when, for the first time, the needle was placed nearly perpendicular to the magnetic meridian, agreeably to the directions given in the report of the Royal Society. Our readers are probably aware that at the present moment a Committee of the British Association is engaged in discussing magnetic observations, and they are anxious to bring together all reasonably good determinations of the solar-diurnal variations of the three magnetic elements for as many places as possible.

It may therefore be of interest, especially after the above remark by Mr. Pogson, to apply some sort of preliminary test to the Madras observations. I shall therefore compare them with the similar results obtained at Bombay, and discussed by Mr. C. Chambers in his recent elaborate and excellent volume.

In the following table we have in the first place a comparison of the solar-diurnal variations of declination at the Colaba Observatory, near Bombay, and at Madras. For the purpose of this comparison it is unnecessary to give the scale values or to exhibit all the months. We have therefore limited our comparisons to a mean of the three months, November, December, and January, and also of the three months, May, June, and July.

TABLE I.-Comparison of the Solar-Diurnal Variations of Declination at Bombay and at Madras

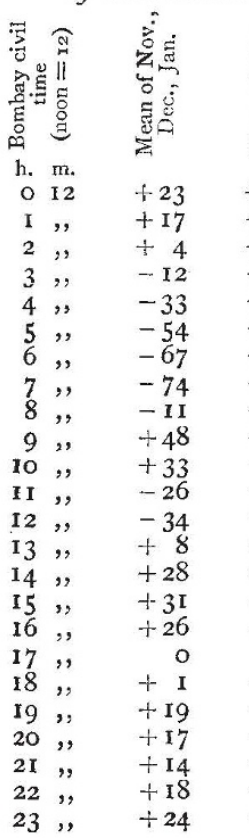

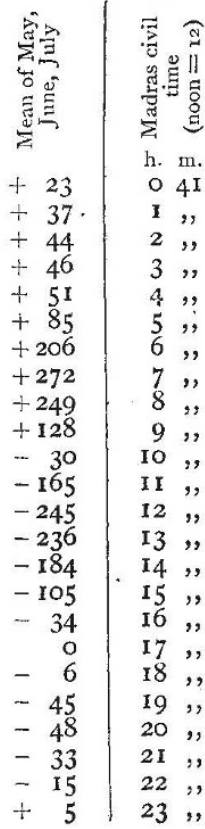

Now it will, we think, be seen from Table I. that at both stations the type as well as the range of the solardiurnal variation is very different for the two groups of months. It will likewise be seen that the peculiarities of the summer variation are very much alike at both stations, and that the peculiarities of the winter variation are also very much alike. Thus the comparison is favourable to the accuracy of the observations at both stations.

Let us now turn to the force components. In Table II. we have a comparison of the horizontal and vertical force variations at the two stations for the two months, June and December.

\section{TABLE II.-Comparison of the Solar-Diurnal Variations of the Horizontal and Vertical Force at Bombay and at Madras}

Bombay civil time $($ noon $=\times 2)$

h. $\mathrm{m}$.

o 18

I , ,

2,

3 ,

4 ,

5,

6 , ,

7 ,

8 ,"

9 ,

II ,

II,

13 ,

I4,

I5,

I6,

I7,

I8,

I9,

20 ,

21 ,"

22 ,

Hori

June
-105

force
Dec.

-96
$-\quad 97$

- 98

$\begin{array}{r}-97 \\ \hline\end{array}$

-88
$-\quad 84$

$97-84$

-94
$-\quad 92$

- 90

-90
$-\quad 47$

-77
-64

- 64

$-50$

$+21$

-25
$+\quad 28$

+ IOI

$+189$

$+287$

$+302$

$+278$

$+214$

$+120$

$+2 \mathrm{I}$

$-56$

$-105$

$-132$

- 124

$-124$

$-121$

- IIg

$+93$

93
+161

$+232$

$+242$

$+204$

$+134$

$+66$

$+17$

$-27$

- 65

$-7:$
$-\quad 86$

$-105$

- II 4

- III
- IOg

Vertical force

June Dec.

$+36$

+37
$+\quad 36$

$+36$

$+30$

$+36$

$+59$

+95
$+\quad 74$

$+74$

$+10$

-80
-153

- 153

$-162$

$-\mathrm{II} 6$
$-\quad 65$

-65
$-\quad 17$

$\begin{array}{r}17 \\ +\quad 19 \\ \hline\end{array}$

$+3 I$

$+22$

$4+8$
$+\quad 3$

$+\mathbf{I} 8+6$

$+2 \mathrm{I}+4$

$+3 \mathrm{r}+9$

$+34+10$

Madras civil time Horizontal force

(noon=12) June Dec.

h. $\mathrm{m}$.

o 4 I

$-309$

$-284$

$-299$

I, ,

$-268$

$-258$

$-243$

-236
-128

$-128$

+58
+365

+365
+658

+658
+873

+873
+876

+876
+716

$+483$

+483
+194

+64
$-\quad 66$

-2 I I

$-28 \mathrm{I}$

$-3 I 9$

$-338$

$-3^{23}$

$-336$

-. 319

-245
-226

-226
-218

$-197$

- 159

$-80$

$+88$

$+317$

$+573$

$+740$

$+730$

$+580$

$+354$

$+160$

$+15$

- 91

-185
-256

$-326$

$-369$

$-374$

- 3II

-341
-314

Vertical force

June Dec.

$+923+666$

$+543+697$

$+757+650$

$+515+529$

$+558+711$

$+617+976$

$+300+879$

$+259+593$

$-533-217$
-1399

$-1329-938$
-1688

- I688-I247

$-1926-1043$

$-1631-1246$

- IOgC - I304

\begin{tabular}{ll}
$-389-872$ \\
\hline
\end{tabular}

$+60.337$

$+24 I-289$
+39

$+30+23$

$+426+75$

$+555+152$

$+596+280$

$+640+376$

$+779+585$

$+991+747$

It will be seen from this table that at both stations and for both components the type for June is nearly the same as that for December, the chief difference being in range. Also that the type at the one station is very similar to that at the other. The most marked difference between the two stations is for the vertical force, the range of this element in December bearing a smaller proportion to its 
range in June at Bombay than at Madras. To investigate this point it will be desirable to give the comparative ranges for the various elements for the various months at the two stations. This is done in the following table.

TABLE III.-Ranges for the Various Months of the Diurnal Variations of the Three Elements at the Two Stations

\begin{tabular}{|c|c|c|c|c|c|c|c|}
\hline \multirow[b]{2}{*}{ Month } & \multicolumn{4}{|c|}{ Bombay } & \multicolumn{3}{|c|}{ Madras } \\
\hline & & $\begin{array}{c}\text { Declina. } \\
\text { tion }\end{array}$ & $\begin{array}{l}\text { Hor. } \\
\text { force }\end{array}$ & $\begin{array}{l}\text { Vert. } \\
\text { force }\end{array}$ & $\begin{array}{l}\text { Declina- } \\
\text { tion }\end{array}$ & $\begin{array}{l}\text { Hor. } \\
\text { force }\end{array}$ & $\begin{array}{l}\text { Vert. } \\
\text { force }\end{array}$ \\
\hline January & $\cdots$ & 162 & 389 & 167 & 9 I & I 318 & 3414 \\
\hline February & $\ldots$ & 117 & 507 & 120 & 64 & 1585 & 3778 \\
\hline March & $\ldots$ & 263 & $57 \mathrm{I}$ & 175 & IO4 & 1785 & 4847 \\
\hline April ... & $\ldots$ & 392 & 576 & 216 & 218 & 1851 & 6273 \\
\hline May ... & $\ldots$ & 486 & 473 & 265 & 243 & 1522 & 4198 \\
\hline June ... & $\ldots$ & 480 & 434 & 257 & 260 & I 2 I 4 & 2917 \\
\hline July ... & $\ldots$ & 468 & 439 & 263 & 249 & 1218 & 244 \\
\hline August & $\ldots$ & 545 & 423 & 301 & 273 & I IOI & 320 \\
\hline September & & 550 & 407 & 365 & 282 & I 33 I & 6401 \\
\hline October & $\ldots$ & $25^{8}$ & 437 & 213 & I IO & I 595 & 516 \\
\hline November & $\cdots$ & 103 & 414 & $9 \mathbf{I}$ & 73 & 1362 & 363 \\
\hline December & $\ldots$ & 136 & 356 & 89 & 86 & $\mathrm{III}_{4}$ & 2280 \\
\hline
\end{tabular}

From this table it will be seen that for both stations there is a smaller maximum of declination range about May or June, and a larger maximum in September, while the most decided minima are in November and February for both stations. Again, there is a maximum of horizontal force range for both stations in April, and also in October while the minima are at Bombay in September and December, and at Madras in August and December.

Finally, at Bombay there is a smaller maximum of vertical force range in May and a larger in September, while at Madras these occur in April and September. The most pronounced minimum of vertical force is in December for both stations.

It would thus appear that there is a very striking likeness between the variations of the three elements at the two stations, and that, notwithstanding Mr. Pogson's remark about the vertical force instrument, its results do not appear to be without value in a comparison of the above nature.

BALFOUR STEWART

\section{PLANTS AND THEIR DEFENCES}

$A$ CONSTANT struggle for existence, the consequence A the enormous increase in the numbers of the every organism, both animal and vegetable. Some have to sustain the attacks of others which are directly antagonistic to them, and which regard them as prey; in the case of others the struggle is rather one to live in the face of adverse conditions or peculiarities of environment, so that the different organisms are not directly hostile, but each affects its neighbour injuriously by adapting itself more readily to the changing surroundings, and so diminishing the other's power of obtaining nutriment, sunlight, or whatever other condition may be the object of their competition. Thus have been developed in the different competitors different features of their constitution-many perfecting powers of active assault, others facilities for active or passive defence. The lastnamed is particularly the feature found in the vegetable kingdom. The want of locomotion prevents any aggressive movement of the individual, and hence success in the struggle can only be secured by more complete adaptation to environment than its competitors can show, or by protective mechanisms guarding the individual from the assaults of organisms inclined to prey upon it. These mechanisms exhibit very great variety, and their object often seems obscure till they are looked at in the light of the environment of the plant, the conditions of its life, and the enemies against which it has to contend. The specially-exposed points of attack are three: the succu- lent leaves and shoots or the attractive fruits are assailed by animals in search of food; the honey secreted by the flower to allure to it the particular insect adapted to bring about properly the process of fertilisation attracts also other insects whose presence is useless for such purpose, and which therefore are only robbers ; while the fertilising pollen is itself the object of desire on the part of others which are equally unable to apply it to its legitimate purpose.

The protective mechanisms of plants, therefore, so far as they are directed against aggressive animals, are to be looked for mainly in the neighbourhood of the young growing parts or the reproductive organs. Not exclusively, however, but generally the older vegetative parts are defended by their own inherent qualities, such as their hardness or wiriness, which keep them from being suitable for the food of their assailants. Such young growing parts in many plants, particularly those growing in exposed regions, are plentifully supplied with thorns, spines, or prickles, rendering them in many cases extremely formidable. The thorns or prickles may be produced on almost all the vegetative organs, and may be merely epidermal structures, or much stronger in composition, containing considerable developments of woody tissue. These thorny plants are most noteworthy in desert countries, some that are met with there, notably the so-called "wait-a-bit" thorn of Africa, having spines of immense length, and being quite impenetrable by man or beast. Cases are not of infrequent occurrence where even the lion himself is a considerable sufferer by coming into collision with this plant. So great is the development of the thorny character in this region that Grisebach connects it particularly with desert exposure and scarcity of vegetation. Nor are thorny plants by any means confined to such regions - on our own heaths the gorse is a familiar plant, and one sufficiently formidable to passers-by ; while other spiny Leguminosæ, as the wrest-harrow (Ononis spinosa), are not infrequent by the wayside. A further peculiarity may be noted in connection with these plants : often the thorns do not occur above the point which is assailable by the animal in its search for food; while, when the shoot has outlived its period of succulent condition, and its tissues have become hard and dry, the thorns do not persist, being much more numerous when the part is young.

Nor is this spiny habit confined to shrubs or trees. The cactuses, which are so remarkable a feature of the vegetation of America, are equally well protected. Their surfaces show great variety of development in this particular: some have small groups of thick rigid spines, others long flexible needles of intense sharpness, penetrating easily the skin of the assailant, and almost impossible to extract.

More formidable defences even than thorns or prickles are found in the varieties of stinging hairs borne so plentifully on the leaves of many plants. These are represented in England by the two species of stinging nettle, which are, as every one knows, capable of producing considerable discomfort to the unwary person who handles them. These are, however, not worth mentioning by the side of many of their tropical relations. The structure of the hair in all these is similar : a mass of cells forms a kind of swollen cushion below; on this is seated the long tapering hair, which ends in a somewhat recurved point or hook. The walls of the upper part of the hair are very strongly silicified, and are, consequently, easily ruptured. Lower down there is but little silica. When touched or rubbed by the hand, the pressure drives the hair downward; at the same time the brittle hook penetrates the skin and breaks off. The downward pressure forces out from the broken hair a fluid of intensely acrid nature, which, on entering the wound made by the point, sets up more or less severe inflammation. This fluid is generally conjectured to be formic acid-a 